A peer-reviewed scholarly journal

Editor: Gene V Glass

College of Education

Arizona State University

Copyright is retained by the first or sole author, who grants right of first publication to the EDUCATION POLICY ANALYSIS ARCHIVES. EPAA is a project of the Education Policy Studies Laboratory.

Articles appearing in EPAA are abstracted in the Current Index to Journals in Education by the ERIC Clearinghouse on Assessment and Evaluation and are permanently archived in Resources in Education.

\title{
Do EMO-operated Charter Schools Serve Disadvantaged Students? The Influence of State Policies
}

\author{
Natalie Lacireno-Paquet \\ The George Washington University
}

Citation: Lacireno-Paquet, N., (2004, June 15). Do EMO-operated charter schools serve disadvantaged students? The influence of state policies. Education Policy Analysis Archives, 12(26). Retrieved [Date] from http://epaa.asu.edu/epaa/v12n26/.

\section{Abstract}

There is a paucity of research about how the policies enacted by states either foster or hinder charter schools' service to disadvantaged students or how the characteristics of charter schools themselves affect this outcome. By combining data from the US Department of Education's Schools and Staffing Survey with data on the characteristics of state charter school policies, this article examines how different types of charter schools respond to the policy and market signals established by state charter legislation, and the impact of such signals on the willingness and ability of charter schools to serve disadvantaged student populations. With a sample of 533 charter schools in 13 states, models are estimated to discern whether specific state policies and whether being managed by two types of for-profit educational management organizations (EMOs)-large and small 
ones-encourages or discourages schools from enrolling low-income and minority students. The results suggest that certain policy characteristics are important for encouraging schools to serve low-income and minority students. Specifically, having multiple chartering authorities and requiring the transportation of students are important for explaining charter schools' service to low-income and minority students. Being managed by a large-EMO was positively but not significantly related to charter schools enrollment of low-income and minority students. The results differed for small-EMO managed schools. Small-EMOs served significantly lower percentages of minority students. The results suggest that not all charter schools are the same and that policy design and organizational form matters for determining whom charter schools will serve.

We are at a crossroads in charter school policy and practice. We are more than ten years from the first law, many state legislatures continue to make amendments to their state charter school laws, and many schools across the nation are having their charters come up for review and renewal. Thus the moment is timely to examine equity issues in charter schools. Forty states and the District of Columbia have enacted charter schools legislation. The extent of charter school activity varies both between and within states. Characteristics of charter schools legislation also vary greatly by states, providing enough natural variation to examine patterns of charter schools service to disadvantaged students. Unlike many education reforms, the charter school idea is a structural reform, not a pedagogical one (Miron and Nelson 2002; Vergari 2002). Proponents of charter schools and the legislators that have adopted variations of this policy believe that by changing the structure within which schools operate, numerous desirable outcomes, such as increased student performance will occur. School choice is also increasingly important because it is one of the cornerstones of the school accountability provisions of the No Child Left Behind Act of 2001. In addition to emphasizing choice as an alternative to students in "failing" Title 1 schools, the federal budget for fiscal year 2002 allocated $\$ 200$ million in grants for "expanding the number of high-quality charter schools available to students across the Nation" (No Child Left Behind Act of $2001 \S 5201(3))$.

Proponents of charter schools argue that they will "provide havens for students who have been poorly served by traditional public schools, promote parental involvement and satisfaction, improve academic achievement, and save public education" (Gill, Timpane et al. 2001, p. xii). The evidence regarding the ability of charter schools to deliver on these promises is quite mixed. No study has proved conclusively that the performance of charter school students is substantially better (or worse) than that of students in traditional public schools. The question of access for underserved populations has generally been examined at an aggregated level. Aggregated at the national level, there tends to be little difference between charter and traditional schools in terms of the enrollment of minority and low-income students (RPP International 2000). Though findings from state and local studies sometimes paint a different portrait. For example, Gill et al. (2001) reported that in 11 out of 27 charter school states, charter schools served a population that had significantly lower 
income than the state's public school population, while in six out of 27 states the opposite was true. With regard to racial and ethnic segregation in charter schools, for example, Cobb and Glass (1999) found that nearly half of the schools in Arizona displayed substantial ethnic segregation. But the research has not yet examined how the policies enacted by states either foster or hinder charter schools' service to disadvantaged students or how the characteristics of charter schools themselves affect this outcome. As charter schools continue to proliferate, it is important to examine the equity implications of this policy and its ability to improve the learning opportunities of the most vulnerable students in the public school system. The aim of this research is to begin to fill part of this information gap by examining how different types of charter schools respond to the policy and market signals established by state charter legislation, and the impact of such signals on the willingness and ability of charter schools to serve disadvantaged student populations.

\section{The Charter Schools Idea}

Charter schools are an idea with several contested meanings and goals (Wells, Grutzik et al. 1999). The founders of the charter movement viewed charter schools as a structural reform that went beyond site-based management to create independent schools that shatter the idea the a one-size fits all model that predominates public school systems (Nathan 1996). But as policymakers took up the idea, the market metaphor for choice and competition came to dominate the discussion (Wells 2002). Thus, along with supply-side arguments for charter schools (innovation, serving diverse needs, increased accountability, etc) are market-based ideas of competition, parental choice and shopping for schools.

The most ardent supporters of school choice base their support in ideas about the operation of the market (Chubb and Moe 1990). Others base their support in providing poor and minority children with options out of poor performing neighborhood schools, in other reform ideas such as site-based management, or in the idea that public schools fail to meet the needs of diverse students (Nathan 1996; Peterson and Greene 1998; Peterson 1999). Much of the discussion about charter schools, indeed, school choice in general, is based on principles of microeconomic theory: that the private market can determine the appropriate quantity and quality of a good by reaching an equilibrium between consumers and producers that optimizes the utility of consumers and the profit of producers. It is also based in the idea that the bureaucracy of governments leads to ineffective and inefficient institutions (Chubb and Moe 1990). These ideas are evident in the definition of charter schools provided by the Center for Education Reform, a pro-charter and school choice organization:

Charter schools are independent public schools, designed and operated by educators, parents, community leaders, educational entrepreneurs and others. They are sponsored by designated local or state educational organizations who monitor their quality and integrity, but allow them to operate freed from the traditional bureaucratic and regulatory red tape that hog-ties public schools. Freed from such micromanagement, charter schools design and deliver programs tailored to educational excellence and community needs. Because they are schools of choice, they are held to the highest level of accountability - 
Proponents of charter schools make numerous claims about the effect of the increased autonomy and accountability that constitute the charter school idea. They argue that autonomy and accountability will lead to schools that improve student performance as measured by standardized test scores and other measures; this will happen because if schools fail to improve student performance and meet other goals as set out in their charter, then their permission to operate can be revoked and/or parents will take their children out of the school signaling a need to change (Nathan 1996). Proponents also recognize that the very idea of charter schools raises equity issues, especially surrounding race, class, and ability-about who will choose or get chosen, about what they will be choosing, and who will be left behind. Some proponents argue that charter schools can reduce class and racial segregation, which they rightly point out is quite extensive in the traditional system, by dissolving the geographic boundaries that result in schools that are reflective of the largely racially and economically segregated neighborhoods in which they are located (Peterson and Greene 1998; Hassel 1999; Viteritti 1999; Greene 2000). Others suggest that allowing schools the autonomy to develop creative and different programs is more equitable than trying to serve all children with similar schools (Nathan 1996).

Those who are wary of school choice, however, fear that it will result in schools selecting students rather than parents selecting schools (Rothstein 1998; Fiske and Ladd 2000; Kahlenberg 2001). Opponents fear that the combination of financial pressures of keeping costs low with the pressure of being increasingly judged by academic performance will lead schools to select a student population that is relatively easy and inexpensive to serve. Those who are wary of choice are also concerned that many parents, especially low-income and immigrant parents, may not have sufficient information to allow them effectively use the mechanism of choice (Henig 1994; Rothstein 1998, Teske and Schneider 2001). There is also some concern that the values and preferences of racial and ethnic minorities may lead them to voluntarily segregate into particular schools. Wells and her colleagues fear that charter schools policies may result in the further isolation of disadvantaged communities and/or that they will fail to redistribute resources to disadvantaged communities resulting in the hardening of race and class hierarchies, thus reinforcing social inequalities (Wells, Lopez et al. 1999).

\section{Educational Management Organizations and Charter Schools}

Most of the research about the impact of charter schools on social stratification and equity treats them as a single class of institution and the results have been mixed (Gill et al. 2001). But there are good reasons to believe that charter schools vary greatly in their orientation to the market and in their missions. Those with a strong orientation to the market tend to have ties to educational management organizations (EMOs), but those that are more mission oriented tend to focus on at-risk populations and often have ties to social service or nonprofit organizations (Lacireno-Paquet, et al. 2002; Henig, et al. 2003). We might expect different equity outcomes from different types of charter schools in diverse policy and market environments. I believe that disaggregating charter 
schools according to their orientation to the market will provide a more nuanced picture of charter schools overall.

Categorizing charter schools according to whether or not they are operated by a for-profit educational management organization is one useful way to gauge market orientation (Miron and Nelson 2002; Lacireno-Paquet, et al. 2002; Brown, et al. 2003). This distinction is useful because while most states require charter schools to take non-profit status as their legal form, most also allow schools to enter into contracts with firms to manage schools and many are choosing to do so. The literature on nonprofit organizations suggests that there are important organizational distinctions between for- and non-profits (Weisbrod 1998; Frumkin and Andre-Clark 2000). While contracting with for-profits is not new to education, what is new is the extent of the contracting arrangements, with new firms sprouting to manage multiple schools across the country (Plank, Arsen et al. 2000; Miron and Nelson 2002). Indeed, the founders of the charter school movement did not envision corporate involvement in charter schools (Nathan 1996).

The concern about EMOs is that the profit motive will lead firms to cut costs, which may negatively affect educational quality and equity (Nelson, et al. 2000; Plank, et al. 2000; Miron and Nelson 2002). To date, only one large-EMO working with charter schools has reported a profit and that is a Michigan based firm called National Heritage Academies (NHA). However, the increasing number of EMOs operating charters schools, "suggests that many more anticipate that profits are just over the horizon" (Miron and Nelson 2002: p.170). There is some evidence that EMO-managed schools tend to serve a different population than mission oriented or more independent schools-one that is less disadvantaged and less expensive to serve (Miron and Nelson 2002; Lacireno-Paquet, et al. 2002).

In their review of school choice outcomes, Teske and Schneider (2001) suggest that stratification in terms of race and class "is the most important question related to school choice" (p. 624). Stratification, they suggest, can be controlled, to some extent, by the institutional mechanisms of forms of choice that are implemented. More importantly, we need to understand the relationship between organizational characteristics of the schools, like EMO-management status, and the types of students served because policymakers can control whether schools are permitted to contract with EMOs and the terms of such contracts.

\section{The Importance of State Policies}

While charter schools can be thought of as a single policy innovation, the way they have been designed and implemented varies from state to state. Studies have shown that certain dimensions of charter school legislation can be important for the emergence of charter schools (Buckley and Kuscova 2003; Witte, Shober et al. 2003). Among the dimensions of variation in state charter school policy regimes that may be important for determining charter schools service to disadvantaged students include: (1) funding; (2) transportation; (3) the number and type of schools permitted; and (4) the number and type of chartering authorities. 
Funding is perhaps the most important policy characteristic because the structure of funding formulas creates incentives and disincentives for charter schools to target particular types of students. Generous formulas not differentiated by grade level or not targeted to the types of student served might lead some schools to target high achieving and low-cost students, especially by those schools hoping to earn a profit because a greater profit can be extracted from a fixed per-pupil allotment if easier and/or less expensive students are served (Plank, et al. 2000; Miron and Nelson 2002). Alternatively, targeted or progressive funding formulas, where schools are reimbursed for additional services, may entice charter operators to target these groups and lead to more equitable service. Funding structures for charter schools are directly under the control of state legislators thus it is important to understand how different funding structures affect equity.

Transportation of students is an important policy variable in understanding how charter schools serve disadvantaged students. If transportation is a family responsibility, it may act as a barrier to low-income families from exercising their choice options. Low-income families may not have the resources (time and/or money) to transport their children to schools, which may be located far from their homes. In states where the transportation of charter students is required, states usually require that either the charter school or the host school district provide it.

In terms of the number of schools permitted, a cap on the total number of charter schools allowed could restrict their impact on traditional schools. Permitting only a small number of schools may actually impede true competition, a key part of the charter concept. While policymakers may try to manage the competition potentially introduced by charter schools, for example, by restricting the total number of schools, these types of policies may result in artificial constraints on the market with unintended consequences for access.

Some charter school policies allow only one set of actors, such as local school districts to grant charters. Others allow a wider variety of public actors to do so. Michigan, for example, permits state universities, community colleges, intermediate and local school districts to grant charters. Buckley and Kuscova (2003) find that:

The institutional environment that states create for their school choice initiatives (or, more accurately, the environment created by political conflict and compromise) can have a profound effect on the performance of policies and programs, including market-based reforms. In our examination of the effect of charter school legislation on market share, we find that one particular set of provisions regarding who can grant charters has a substantial effect on their share of a market for education (p.16).

The number and types of actors that can grant charters also likely influences the types of schools that get approved and can also affect the issue of stratification. Local school districts have been wary of authorizing charter schools, which they see as their competitors (Hassel 1999). Some authorizers, such as the university authorizers in Michigan, have favored granting charters to schools that partner with EMOs but school district authorizers there have the 
opposite tendency (Miron and Nelson 2002).

\section{Research Questions}

Empirical evidence about charter schools and the surrounding public school districts can be used to answer questions about whether the market will exacerbate or ameliorate race and class based segregation in certain policy environments. Here I begin to address these questions by examining how different types of charter schools-specifically EMO and non-EMO operated schools-respond to the policy and market signals established by state charter legislation and how this affects their service to disadvantaged student populations (Note 1). By combining data on state charter school laws with data from the 1999-2000 Schools and Staffing Survey (SASS), a National Center for Education Statistics survey, I begin to discern important variations in policy features and in charter school organizational characteristics that influence charter schools service to disadvantaged students. Finding that different policy characteristics and/or school organizational characteristics are associated with the under-serving or under-enrollment of traditionally disadvantaged students would suggest policy alternatives to manage competition while safeguarding the public values of equity and choice.

\section{Data and Methods}

The data for this research come from multiple sources. School level data on charter schools and data on the districts in which these schools are located ("host districts") come from the 1999-2000 Schools and Staffing Survey. The SASS is a periodic survey conducted by the National Center for Education Statistics of the US Department of Education. SASS included a charter school component for the first time in the 1999-2000 data collection, when the population of charter schools was surveyed. The SASS also included a sample of public school districts from each state in the nation. Using the Common Core of Data, a yearly census survey of schools and districts in the nation, I used charter school zip codes to identify the host districts for all charter schools responding to the SASS. Because districts were only sampled, not all charter school host districts were included in the SASS. About half of the host districts were identified, but these represented the host districts of more than 78 percent of all of the charter schools in the sample. Only charter schools with host districts identified were included in this analysis. These school and district level data form the base of the analysis file. After excluding schools in states that did not have an EMO operated school responding to the survey, 587 schools in 13 states remained in the analysis file. (Note 2) Another 54 schools with missing data for the dependent variables were excluded, resulting in 533 charter schools in 216 districts being included in the analysis. Table 1 lists the states that were included in this study, as well as the number of charter schools responding to the SASS in the 1999-2000 school year, and the number of host districts identified in SASS.

\section{Table 1. States in Analysis Sample}




\begin{tabular}{|l|c|c|c|c|}
\hline State & $\begin{array}{c}\text { Total } \\
\text { Number } \\
\text { of } \\
\text { Charter } \\
\text { Schools }\end{array}$ & $\begin{array}{c}\text { Number of } \\
\text { Charter } \\
\text { Schools } \\
\text { Responding to } \\
\text { SASS } \\
\text { (1999-2000) }\end{array}$ & $\begin{array}{c}\text { Number of } \\
\text { Charter } \\
\text { Schools } \\
\text { with Host } \\
\text { Districts } \\
\text { Identified } \\
\text { (Sample) }\end{array}$ & $\begin{array}{c}\text { Year } \\
\text { Charter } \\
\text { School } \\
\text { Legislation } \\
\text { Passed }\end{array}$ \\
\hline Arizona & 180 & 173 & 115 & 1994 \\
\hline California & 154 & 113 & 84 & 1992 \\
\hline Colorado & 60 & 52 & 36 & 1993 \\
\hline District of & 19 & 16 & 15 & 1996 \\
\hline Columbia & 72 & 59 & 57 & 1996 \\
\hline Florida & 20 & 10 & 10 & 1996 \\
\hline Illinois & 34 & 27 & 16 & 1993 \\
\hline Massachusetts & 131 & 119 & 72 & 1993 \\
\hline Michigan & 38 & 29 & 24 & 1991 \\
\hline Minnesota & 30 & 24 & 10 & 1996 \\
\hline New Jersey & 56 & 42 & 29 & 1996 \\
\hline North Carolina & 31 & 23 & 14 & 1997 \\
\hline Pennsylvania & 109 & 71 & 51 & 1996 \\
\hline Texas & 914 & 748 & 533 & \\
\hline Total & & & & \\
\hline & 51 & 59 & \\
\hline
\end{tabular}

* Excludes charter schools with missing data for the number of FARL-eligible and minority students.

Sources: RPP International 2000; Authors calculations using the 1999-2000 Schools and Staffing Survey Data.

Data on the characteristics of state charter school legislation come from two sources, both commissioned by the US Department of Education. Data on the financial aspects of state charter legislation comes from Nelson, Muir and Drown's (2000) Venturesome Capital and data on the caps and other non-financial characteristics are from RPP International's (1999) A Comparison of Charter School Legislation. Table 2 below tabulates the number of states in this study having each policy variable of interest.

Variables included in the models come from the state, district, and school levels. Each level and the variables included are explicated in more detail below. OLS regression models with schools clustered by their host district were estimated for the percent of students eligible for Free and Reduced Price Lunch (Note 3 ) and the percent of minority students in charter schools. (Note 4) Each 
model will be discussed in detail below.

\begin{tabular}{|l|c|c|}
\hline Table 2: Frequency of State Policy Characteristics \\
\hline Policy & $\begin{array}{c}\text { Number (Percent) } \\
\text { of States Without } \\
\text { Policy Feature }\end{array}$ & $\begin{array}{c}\text { Number (Percent) } \\
\text { of States With } \\
\text { Policy Feature }\end{array}$ \\
\hline $\begin{array}{l}\text { Cap on number of charter } \\
\text { schools in state }\end{array}$ & $\begin{array}{c}6 \\
(46.15)\end{array}$ & $\begin{array}{c}7 \\
(53.85)\end{array}$ \\
\hline Multiple Authorizers & 7 & 6 \\
$(53.85)$ & $(46.15)$ \\
\hline $\begin{array}{l}\text { State Level Authorizer } \\
\text { Only }\end{array}$ & 11 & 2 \\
\hline $\begin{array}{l}\text { Local School District } \\
\text { Authorizers Only }\end{array}$ & $(84.61)$ & $(15.38)$ \\
\hline $\begin{array}{l}\text { Funding for Charter } \\
\text { Schools Varies by Grade } \\
\text { Levels Served }\end{array}$ & 9 & 4 \\
\hline $\begin{array}{l}\text { State Provides Funding } \\
\text { for At-Risk or Low-Income } \\
\text { Students }\end{array}$ & $(46.15)$ & $(30.77)$ \\
\hline $\begin{array}{l}\text { Transportation Not } \\
\text { Required for Charter } \\
\text { Students }\end{array}$ & $(30.77)$ & 7 \\
\hline
\end{tabular}

Sources: RPP International 1999; Nelson, Muir et al. 2000

\section{State Policy Characteristics}

As noted above, some of the significant dimensions of variation in state charter school policy regimes represented by variables in the model include: (1) funding; (2) transportation; (3) number of schools permitted; and (4) number and types of chartering authorities. More specifically, the funding variables included in the models are whether the state provides additional funding for at-risk or low-income students and another to indicate whether funding varies by the grade levels served. A variable is included to indicate whether transportation of charter students is required (either by the school or the district).

Another variable is included to indicate whether or not a state has a cap on the number of charter schools permitted. Also, a variable is included to indicate whether the state has multiple chartering authorities compared to having only one authorizer. In cases where there is only one chartering authority, it is usually local school districts, though a few states have a state-level charter authorizing board or agency. States with multiple authorities usually allow local school districts and other, usually state level, entities to charter schools, such as public universities or state boards of education. 


\section{District Characteristics}

Characteristics of the local school district in which charter schools are located are also important because they affect both whether and what types of charter school are likely to operate in a district and what charter schools are likely to do in terms of targeting students once they open. Important explanatory variables at this level include the percentage of students in the district who are eligible for the federal Free and Reduced Price Lunch (FARL) program and the percentage of minority students (all calculated excluding charter schools) because they are populations considered at-risk for educational failure or considered underserved by traditional schools. These variables are also important because charter schools primarily draw students from their host district and consequently their enrollments may be strongly influenced by the composition of student population of their districts. Miron, Neslon, and Risley (2002) found, for example, that the average charter school student in Pennsylvania travels 5.5 miles to attend a charter school. A variable for the size of the district (measured as the natural log of total district enrollment) was included to control for the size of the market in which a charter school operates.

\section{School Characteristics}

The main school level variable that is predicted to influence charter school service to disadvantaged students is charter school type. (Note 5) Charter schools are disaggregated into schools managed by large-EMOs-defined as those managing 10 or more schools-and those managed by small-EMOs-defined as those managing at least three but fewer than 10 schools. The category 'large-EMO' includes the following for-profit management firms in existence at the time of the SASS data collection: Advantage, Beacon, Edison, Leona, Mosaica, National Heritage Academies, and SABIS.

Small-EMOs include firms such as Smart Schools, Inc., Designs for Learning, and others similar private, for-profit firms that operate fewer than 10 schools, usually in only one state. These two EMO categories are contrasted against the excluded category of non-EMO managed charter schools. The differences in market oriented and more independent charter schools are important because each type is likely to respond differently to both the policy environment and the market for education in terms of where they locate, the programs they offer, and the students they serve.

Other variables that may affect a school's service to disadvantaged students include whether the school is specifically for at-risk students, whether the school has admissions criteria, whether the school requires parents to volunteer, and the age of the school. The grade levels offered by a school (elementary, elementary/middle, and high school) are also controlled for in the models in order to see whether the patterns are different by grade level. School size is controlled for by including a variable of the total number of students enrolled in the school. The urban location of schools is also controlled for. Charter schools in this sub-sample are all rather urban but a variable is used to indicate whether the school is located in the central city of a large or mid-sized city. (Note 6) 


\section{Results}

As noted above each dependent variable of interest was modeled as a function of school, district, and state policy characteristics. Variables are defined in Table 3. The basic model is shown below. For a school $i$ in district $j$ and state $k$ : (Note 7)

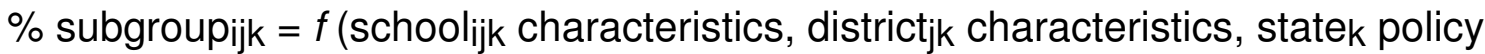
characteristics)

\section{Table 3: Variable Definitions}

\begin{tabular}{|c|c|}
\hline Variable Name & Definition \\
\hline Minority Enrollment & $\begin{array}{l}\text { The percent of students who are Black, } \\
\text { Hispanic, American Indian or Alaska Native } \\
\text { American; continuous variable. }\end{array}$ \\
\hline $\begin{array}{l}\text { Percent FARL-eligible } \\
\text { Students in School }\end{array}$ & $\begin{array}{l}\text { Percent of K-12 plus ungraded students who } \\
\text { are eligible to participate in the Free and } \\
\text { Reduced Price Lunch Program; continuous } \\
\text { variable. }\end{array}$ \\
\hline $\begin{array}{l}\text { Large-EMO-managed } \\
\text { School }\end{array}$ & $\begin{array}{l}\text { Dichotomous variable equals } 1 \text { if school is } \\
\text { operated by a large Educational } \\
\text { Management Organization (one that } \\
\text { operates } 10 \text { or more charter schools). }\end{array}$ \\
\hline $\begin{array}{l}\text { Small-EMO-managed } \\
\text { School }\end{array}$ & $\begin{array}{l}\text { Dichotomous variable equals } 1 \text { if school is } \\
\text { operated by a small Educational } \\
\text { Management Organization (one that } \\
\text { operates at least } 3 \text { but fewer than } 10 \text { charter } \\
\text { schools). }\end{array}$ \\
\hline Non-EMO Charter School & $\begin{array}{l}\text { Omitted variable. Reference category which } \\
\text { includes all charter schools not managed by } \\
\text { an EMO. }\end{array}$ \\
\hline At-Risk School & $\begin{array}{l}\text { Dichotomous variable equals } 1 \text { if school is } \\
\text { exclusively for at-risk or expelled students or } \\
\text { those involved in the criminal justice system }\end{array}$ \\
\hline Admissions Criteria & $\begin{array}{l}\text { Dichotomous variable equals } 1 \text { if the school } \\
\text { uses one or more admissions criteria (such } \\
\text { as standardized test scores) for admissions } \\
\text { decisions }\end{array}$ \\
\hline $\begin{array}{l}\text { Number of Years in } \\
\text { Operation }\end{array}$ & $\begin{array}{l}\text { Continuous variable indicating the total } \\
\text { number of years a school has been offering } \\
\text { classes as a charter school. }\end{array}$ \\
\hline Total Enrollment & $\begin{array}{l}\text { Total number of students in grades } \mathrm{K}-12 \text { ano } \\
\text { any ungraded students }\end{array}$ \\
\hline
\end{tabular}




\begin{tabular}{|c|c|}
\hline $\begin{array}{l}\text { Parents Required to } \\
\text { Volunteer }\end{array}$ & $\begin{array}{l}\text { Dichotomous variable equals } 1 \text { if the school } \\
\text { requires parents to volunteer some amount } \\
\text { of time at the school as a requirement for } \\
\text { student enrollment. }\end{array}$ \\
\hline Middle School & $\begin{array}{l}\text { Dichotomous variable equals } 1 \text { if the school } \\
\text { exclusively serves the middle school grades. }\end{array}$ \\
\hline High School & $\begin{array}{l}\text { Dichotomous variable equals } 1 \text { if the school } \\
\text { exclusively serves the high school grades. }\end{array}$ \\
\hline Other Grades & $\begin{array}{l}\text { Dichotomous variable equals } 1 \text { if the school } \\
\text { serves other or combined grade } \\
\text { configurations (i.e. k-12). }\end{array}$ \\
\hline Elementary Grades & $\begin{array}{l}\text { Omitted category to which other grade levels } \\
\text { are compared. }\end{array}$ \\
\hline $\begin{array}{l}\text { School Located in Central } \\
\text { City of Large or Mid-Sized } \\
\text { City }\end{array}$ & $\begin{array}{l}\text { Dichotomous variables equals } 1 \text { if the school } \\
\text { is located in the central city of a large or } \\
\text { mid-sized city, as compared to the urban } \\
\text { fringe of a city or rural areas. }\end{array}$ \\
\hline District Percent Minority & $\begin{array}{l}\text { Percent of K-12 plus ungraded students in a } \\
\text { district who are Black, Hispanic, Native } \\
\text { American or Alaska Native; Continuous } \\
\text { variable. }\end{array}$ \\
\hline $\begin{array}{l}\text { District Percent } \\
\text { FARL-eligible }\end{array}$ & $\begin{array}{l}\text { Percent of K-12 plus ungraded students in a } \\
\text { district who are eligible for the Free and } \\
\text { Reduced Lunch Program; continuous } \\
\text { variable. }\end{array}$ \\
\hline Log of District Enrollment & $\begin{array}{l}\text { Natural log of total number of students } \\
\text { enrolled in the host district. }\end{array}$ \\
\hline Cap & $\begin{array}{l}\text { Dichotomous variable equals } 1 \text { if state policy } \\
\text { includes a limit or cap on the number of } \\
\text { charter schools allowed statewide. }\end{array}$ \\
\hline Multiple Authorizers & $\begin{array}{l}\text { Dichotomous variable equals } 1 \text { if state policy } \\
\text { allows more than one type of agency to } \\
\text { grant charters. Contrasted against policy that } \\
\text { allows only one authorizer (either state or } \\
\text { local school districts). }\end{array}$ \\
\hline $\begin{array}{l}\text { Funding Varies by Grade } \\
\text { Level }\end{array}$ & $\begin{array}{l}\text { Dichotomous variable equals } 1 \text { if the state } \\
\text { policy includes a funding formula that varies } \\
\text { the per pupil amount by the grade level of } \\
\text { the student. }\end{array}$ \\
\hline State Funds for At-Risk & $\begin{array}{l}\text { Dichotomous variable equals } 1 \text { if the state } \\
\text { provides additional funds for at-risk or } \\
\text { low-income students in addition to any } \\
\text { federal funds for which a school may be }\end{array}$ \\
\hline
\end{tabular}


eligible.

Transportation not required

Dichotomous variable equals 1 if the state policy does not specify or require that either the charter school or the host district provide transportation to charter school students.

The results of each estimated model are described below. Tables 4 and 5 show the means and standard deviations for continuous variables, and the tabulations for the dummy variables. Table 6 presents the results of the multivariate regressions.

\begin{tabular}{|l|c|}
\hline Table 4: Tabulations for Variables of Interest & $\begin{array}{l}\text { Number of } \\
\text { Schools }\end{array}$ \\
\hline Variable & 69 \\
\hline Total Number of EMO-managed Schools & 49 \\
\hline Number of Large-EMO-managed Schools & 23 \\
\hline Number of Small-EMO-managed Schools & 464 \\
\hline Number of Non-EMO-managed Schools & 30 \\
\hline $\begin{array}{l}\text { Number of Schools for At-Risk or Expelled Students or } \\
\text { Students who Dropped Out }\end{array}$ & 138 \\
\hline Number of Schools with Admissions Criteria & 236 \\
\hline Number of Schools Requiring Parents to Volunteer & 278 \\
\hline Number of Elementary Schools & 46 \\
\hline Number of Middle Schools & 115 \\
\hline Number of High Schools & 94 \\
\hline $\begin{array}{l}\text { Number of Schools Serving Other Grades, or Other } \\
\text { Grade Configurations }\end{array}$ & 347 \\
\hline $\begin{array}{l}\text { Number of Schools in Central City of Large or Mid-Sized } \\
\text { Central Cities }\end{array}$ & \\
\hline
\end{tabular}

\section{Table 5: Table of Means and Standard Deviations}

\begin{tabular}{|l|l|l|l|}
\hline Variable & Mean & $\begin{array}{l}\text { Standard } \\
\text { Deviation }\end{array}$ & $\begin{array}{l}\text { Minimum - } \\
\text { Maximum }\end{array}$ \\
\hline Full Sample $(\mathrm{N}=533)$ & \multicolumn{3}{|l|}{} \\
\hline Percent FARL-eligible in school & 50.54 & 31.32 & $0.22-100$ \\
\hline Minority Enrollment & 59.15 & 35.36 & $0-100$ \\
\hline Years in Operation & 2.61 & 1.54 & $1-8$ \\
\hline Total Enrollment & 290.13 & 326.12 & $12-2,653$ \\
\hline
\end{tabular}




\begin{tabular}{|c|c|c|c|}
\hline Log of District Enrollment & 10.24 & 1.59 & $5.30-13.47$ \\
\hline $\begin{array}{l}\text { District Percent FARL-eligible } \\
\text { students }(N=532)\end{array}$ & 46.05 & 21.76 & $0.57-100$ \\
\hline $\begin{array}{l}\text { District Percent minority } \\
\text { students }\end{array}$ & 56.58 & 29.99 & $0.39-99.92$ \\
\hline \multicolumn{4}{|c|}{ Non-EMO managed Schools $(\mathrm{N}=464)$} \\
\hline Percent FARL-eligible in school & 49.96 & 31.62 & $0.22-100$ \\
\hline Minority Enrollment & 58.66 & 35.42 & $0-100$ \\
\hline Years in Operation & 2.69 & 1.57 & $1-8$ \\
\hline Log of District Enrollment & 10.24 & 1.61 & $5.30-13.47$ \\
\hline $\begin{array}{l}\text { District Percent FARL-eligible } \\
\text { students }(N=463)\end{array}$ & 45.44 & 22.35 & $0.57-100$ \\
\hline $\begin{array}{l}\text { District Percent minority } \\
\text { students }\end{array}$ & 55.75 & 30.08 & $0.39-99.92$ \\
\hline \multicolumn{4}{|c|}{ Large-EMO-Managed Schools ( $\mathrm{N}=23$ ) } \\
\hline Percent FARL-eligible in school & 63.00 & 26.97 & $1.82-100$ \\
\hline Minority Enrollment & 68.20 & 34.14 & $1.54-100$ \\
\hline Years in Operation & 1.85 & 0.92 & $1-4$ \\
\hline Log of District Enrollment & 10.04 & 1.32 & $7.57-12.93$ \\
\hline $\begin{array}{l}\text { District Percent FARL-eligible } \\
\text { students }\end{array}$ & 51.60 & 16.31 & $11.85-86.45$ \\
\hline $\begin{array}{l}\text { District Percent minority } \\
\text { students }\end{array}$ & 62.23 & 28.51 & $3.71-99.40$ \\
\hline \multicolumn{4}{|c|}{ Small-EMO-Managed Schools $(\mathrm{N}=23)$} \\
\hline Percent FARL-eligible in school & 50.16 & 26.77 & $6.52-94.34$ \\
\hline Minority Enrollment & 50.98 & 34.62 & $3-100$ \\
\hline Years in Operation & 2.35 & 1.37 & $1-6$ \\
\hline Log of District Enrollment & 10.56 & 1.67 & $6.57-12.37$ \\
\hline $\begin{array}{l}\text { District Percent FARL-eligible } \\
\text { students }\end{array}$ & 47.37 & 18.11 & $8.95-79.94$ \\
\hline $\begin{array}{l}\text { District Percent minority } \\
\text { students }\end{array}$ & 61.98 & 30.58 & $8.77-95.74$ \\
\hline
\end{tabular}

Table 6: OLS Regression With Robust Standard Errors, Clustered by Host District 


\begin{tabular}{|c|c|c|}
\hline Variable & $\begin{array}{c}\text { Percent of } \\
\text { FARL-eligible Students } \\
\text { in School }\end{array}$ & $\begin{array}{c}\text { Percent of } \\
\text { minority students } \\
\text { in School }\end{array}$ \\
\hline \multicolumn{3}{|l|}{ School Level Variables } \\
\hline Large-EMO school & $\begin{array}{c}4.49 \\
(4.57)\end{array}$ & $\begin{array}{l}3.94 \\
(3.40)\end{array}$ \\
\hline Small-EMO School & $\begin{array}{l}-0.30 \\
(5.66)\end{array}$ & $\begin{array}{c}-10.44^{\star *} \\
(3.90)\end{array}$ \\
\hline Non-EMO Charter School & Omitted & Omitted \\
\hline $\begin{array}{l}\text { School for at-risk students } \\
\text { only }\end{array}$ & $\begin{array}{l}11.81 \\
(6.50)\end{array}$ & $\begin{array}{l}-1.34 \\
(4.64)\end{array}$ \\
\hline Admission Criteria & $\begin{array}{l}-5.85^{\star} \\
(2.87)\end{array}$ & $\begin{array}{l}-1.92 \\
(3.22)\end{array}$ \\
\hline $\begin{array}{l}\text { Parents Required to } \\
\text { Volunteer }\end{array}$ & $\begin{array}{l}-3.77 \\
(2.95)\end{array}$ & $\begin{array}{l}2.35 \\
(2.59)\end{array}$ \\
\hline $\begin{array}{l}\text { Number of Years in } \\
\text { Operation }\end{array}$ & $\begin{array}{l}1.12 \\
(0.99)\end{array}$ & $\begin{array}{l}-0.20 \\
(0.78)\end{array}$ \\
\hline Middle School Grades Only & $\begin{array}{l}-0.94 \\
(5.19)\end{array}$ & $\begin{array}{l}2.11 \\
(4.68)\end{array}$ \\
\hline High School Grades Only & $\begin{array}{l}-3.52 \\
(2.80)\end{array}$ & $\begin{array}{l}-0.33 \\
(2.57)\end{array}$ \\
\hline Combined Grades & $\begin{array}{c}2.64 \\
(3.68)\end{array}$ & $\begin{array}{l}-0.87 \\
(3.29)\end{array}$ \\
\hline Elementary Grades & Omitted & Omitted \\
\hline Total Enrollment & $\begin{array}{l}-0.005 \\
(0.004)\end{array}$ & $\begin{array}{l}0.003 \\
(0.003)\end{array}$ \\
\hline $\begin{array}{l}\text { School Located in Central } \\
\text { City of Large or Mid-sized } \\
\text { City }\end{array}$ & $\begin{array}{l}6.35^{*} \\
(3.15)\end{array}$ & $\begin{array}{l}5.70 \\
(3.37)\end{array}$ \\
\hline \multicolumn{3}{|l|}{ District Level Variables } \\
\hline $\begin{array}{l}\text { Percent FARL-Eligible in } \\
\text { District }\end{array}$ & $\begin{array}{l}0.45^{* * *} \\
(0.06)\end{array}$ & -- \\
\hline Percent Minority in District & -- & $\begin{array}{l}0.72^{\star \star *} \\
(0.05)\end{array}$ \\
\hline Log of District Enrollment & $\begin{array}{c}0.54 \\
(1.01)\end{array}$ & $\begin{array}{c}0.18 \\
(0.96)\end{array}$ \\
\hline \multicolumn{3}{|l|}{ State Level Policy Variables } \\
\hline Cap on Number of Schools & $\begin{array}{l}-1.57 \\
(3.43)\end{array}$ & $\begin{array}{l}-5.40^{*} \\
(2.74)\end{array}$ \\
\hline
\end{tabular}




\begin{tabular}{|c|c|c|}
\hline Multiple Authorizers & $\begin{array}{c}17.79^{\star * *} \\
(4.86)\end{array}$ & $\begin{array}{c}14.11^{\star * *} \\
(3.33)\end{array}$ \\
\hline $\begin{array}{l}\text { Funding Varies by Grade } \\
\text { Level Served }\end{array}$ & $\begin{array}{l}-5.60 \\
(4.15)\end{array}$ & $\begin{array}{l}-5.50 \\
(2.92)\end{array}$ \\
\hline $\begin{array}{l}\text { State Funding for At-risk } \\
\text { Students }\end{array}$ & $\begin{array}{c}5.98 \\
(5.39)\end{array}$ & $\begin{array}{c}1.21 \\
(3.24)\end{array}$ \\
\hline $\begin{array}{l}\text { Transportation Not } \\
\text { Required }\end{array}$ & $\begin{array}{c}-22.29^{* * *} \\
(4.84)\end{array}$ & $\begin{array}{c}-19.89^{* * *} \\
(3.85)\end{array}$ \\
\hline \multicolumn{3}{|l|}{ Constant } \\
\hline Constant & $\begin{array}{l}23.40 \\
(10.29)\end{array}$ & $\begin{array}{l}20.47 \\
(10.08)\end{array}$ \\
\hline \multicolumn{3}{|l|}{ Model Properties } \\
\hline Number of Observations & 532 & 533 \\
\hline Number of Clusters & 215 & 216 \\
\hline F Statistic & $F(18,214)=9.99^{* * *}$ & $\begin{array}{l}\mathrm{F}(18,215)= \\
48.91^{* * \star}\end{array}$ \\
\hline R-Squared & 0.2156 & 0.5102 \\
\hline
\end{tabular}

Note: Standard error in parentheses. ${ }^{*} p \leq .05,{ }^{* *} p \leq .01,{ }^{* * *} p \leq 0.001$

\section{Percent of Free and Reduced Lunch Eligible Students}

The average percentage of students eligible for Free and Reduced Lunch, in all charter schools combined, is 50.54 percent, but there are differences by school type. For EMO-managed schools as a group the average is 56.52 percent, for large-EMO-managed schools it is 63.00 percent and 50.16 percent for small-EMO-managed schools. For all other charter schools the average is 49.96 percent. Do these patterns of FARL-eligible enrollment hold in a multivariate analysis?

The multivariate regression is significant overall, with an F-statistic of 9.99. The model explains a fair amount of variation in our dependent variable (R-squared 0.2156), the percentage of FARL-eligible students in a school. The coefficient on the variable indicating management by a large-EMO is positive but not statistically significant, suggesting no difference in FARL-eligible enrollment between large-EMO and non-EMO operated charter schools. Small-EMO charter schools also do not enroll significantly different percentages of FARL-eligible students, when controlling for all of the other variables. Only two school level variables reach statistical significance: having admissions criteria and urban location. Schools that have admission requirements tend to enroll a lower percentage of FARL-eligible students, indicated by the significant coefficient of -5.85 . Charter schools in urban areas enroll about 6.35 percentage points more FARL-eligible students, all else constant.

One district characteristic variable is important in explaining the variation in the 
percent of FARL-eligible students in charter schools. The coefficient (0.45), though small, suggests that the higher the percentage of FARL-eligible students in the district, the higher the percentage in charter schools. It is not surprising that, all else constant, the percentage of FARL-eligible students in a districts is related to the percentage of FARL-eligible students in charter schools as charters likely draw most of their students from the district in which they are located.

The variables representing state policy characteristics present some interesting results. While only two of the variables have significant coefficients, the magnitudes are strikingly large. Having multiple chartering authorities, as opposed to only one type of authorizer-usually a state level agency or local school districts-is positively and significantly related to the percentage of FARL-eligible students served in a school; the coefficient of 17.79 suggests that schools in states with multiple charter authorities enroll about 18 percentage points more Free and Reduced Lunch-eligible students than schools in states with only one authorizer. There has been speculation that local school districts are wary of authorizing charter schools that they see as competitors and so when they do authorize a charter school, it is usually for a school with a special program or serving a special population, which may not encourage service to low-income students.

Not surprisingly, the variable indicating that the transportation of charter school students (either by the schools or districts) is not required was also significant but with a large negative effect on the percentage of low-income students in a school, with a coefficient of -22.29 . Schools located in states that do not require the transportation of students to charter schools enroll about 22 percentage points fewer low-income students than schools in states that do require transportation of charter students.

\section{Minority Enrollment}

Minority enrollment in charter schools averages about 59.15 percent. Enrollment, however, varies greatly by charter school type. Minority students comprise about 68.20 percent of large-EMO managed schools but only 50.98 percent of small-EMO managed schools. The minority enrollment of non-EMO charter schools falls in between at $\mathbf{5 8 . 6 6}$ percent. Again, the multivariate analysis is performed to see whether these differences remain when policy variables, and other school and district variables are taken into account.

Minority enrollment is defined as the percentage of all students in a school who are Asian or Pacific Islander, Black or African American, Hispanic, or Native American or Alaska Native, or the percentage of non-White students. This model was estimated similarly to the model of FARL-eligibility except with a variable controlling for the percent of minority students in the host district. The model is significant overall with an F-statistic of 48.91 and an R-squared of 0.5102 .

With regard to the school level variables, we see that EMO status is important for explaining the variation in minority enrollment. Charter schools managed by small-EMO firms enroll a significantly lower percentage of minority students, 
about 10 percentage points lower, even controlling for the other school, district, and state policy variables. No other school level variables are significant in this model.

At the district level the variable controlling for the minority enrollment of the host district is significant. The coefficient of 0.72 suggests that as the minority enrollment of a charter school's host district increases, so too does that of the charter school. This is not surprising given the fact that charter schools tend to draw most of their students from their surrounding host district.

In this model, the state level policy variables also present dramatic results. Consistent with the FARL-eligible model above, the variables multiple authorizers and not requiring transportation have large and significant coefficients. Additionally, the variable having a cap on the total number of charter schools has a significant and negative coefficient. The coefficient of -5.40 suggests that schools in states with caps have minority enrollments that are about 5 percentage points lower than those in states without caps. The coefficient on multiple authorizers is 14.11 suggesting that this policy characteristic plays a large role in encouraging charter schools to enroll minority students. Again, we find that not requiring transportation has a large negative effect. In this case, not requiring the transportation of charter school students reduces the percent of minority students in charter schools by about 20 points compared to schools in states that require transportation, all else constant.

\section{Conclusions}

The findings presented here suggest that certain policy characteristics are important for encouraging all types of charter schools to enroll low-income and minority students. Most notably, having multiple authorizers, rather than only local school districts or only state level authorizers, and requiring the transportation of charter school students appear to lead schools to serve higher percentages of FARL-eligible and minority students. Diverse chartering authorities are likely to authorize diverse types of schools across a state, whereas the biases and preferences of a single authorizing body are likely to dictate the types of schools that open. In states where local school districts are the only authorizers, for example, districts may be wary of the competition brought by charter schools or they may use charter schools as a place to channel more difficult or expensive to serve students. Policymakers need to realize that their choice of charter authorizers will influence the types of students served by charter schools.

States where transportation for charter school students is not required, not surprisingly, keeps the percentage of FARL-eligible and minority students lower than in schools in states where some kind of transportation of charter students is required. Indeed, it has been a concern of those wary of school choice that transportation would be a barrier to low-income families to execute their choice options. Low-income families may not have the resources (time and/or money) to transport their children to schools, which may be located far from their homes. Policymakers concerned about access to charter schools need to ensure that the transportation of charter school students is provided. 
The organizational form of the school-that is association with a large or small-EMO_-appears to be important in explaining a school's service to minority students. Disaggregating the category of EMO operated schools into large- and small-EMOs proved to be important because the patterns were not consistent between the two types of firms. Large-EMOs, for instance, do not serve significantly higher or lower percentages of low-income and minority students than all other types of charter schools. But schools managed by small-EMO schools served much lower percentages of minority students than all other charter schools.

\section{Policy Implications}

Policy matters for who gets served by charter schools and the devil is indeed in the details. Policymakers, educational professionals, and interested citizens need to be thoughtful and deliberate about the kinds of charter schools they want. If equity concerns are the most prominent, then policymakers need to be sure those aspects of the law dealing with the authorization of schools, transportation, and others, have the desired effects.

The results for EMO operated schools are mixed. Large-EMOs do not appear to under- or over-enroll low-income and minority students whereas small-EMO operated charter schools enroll significantly lower percentages of minority students. But recall that the data used in this study are cross-sectional and it is important to monitor the constantly evolving charter school landscape to determine if the findings reported here become trends or not. The number of EMOs is growing, as is the number of schools they operate, and the number of students they serve. Indeed, six of the largest EMOs (Charter Schools USA, Chancellor Beacon Academies, Edison Schools Inc., Mosaica, National Heritage Academies, and White Hat Management) recently formed a Washington, DC based interest group called the National Council of Education Providers (National Council 2004). The organization plans to use its collective clout as the employers of more than 14,000 employees and the educators of more than 140,000 students in 24 states to increase public funds for charter schools and to influence state and federal legislation affecting charter schools (Archer 2004). In this analysis, only about 8 percent of the charter schools are EMO-operated. It remains to be seen what will happen if EMOs come to manage more and more charter schools. Policymakers have the power to decide whether EMOs can operate in their state. School founders also have control over the organizational form they choose, including partnering with for-profit EMOs. School leaders need to think about their missions and goals in designing their schools, and policymakers need to think about the purposes and goals of the reform in designing or amending the policy.

\section{Acknowledgment}

This research was supported by a grant from the American Educational Research Association which receives funds for its "AERA Grants Program" from the U.S. Department of Education's National Center for Education Statistics, and the Institute for Education Sciences, and the National Science Foundation under NSF Grant \#REC-9980573. Opinions reflect those of the author and do 
not necessarily reflect those of the granting agencies. The author would like to thank the anonymous reviewers, as well as Jeffrey Henig, Christopher Nelson, and Linda Renzulli for their helpful comments on earlier drafts. The author is responsible for any errors presented here. An earlier version of this paper was presented at the Annual Research Conference of the Association for Public Policy and Management, November 7-9, 2002, Dallas, TX.

\section{References}

Archer, Jeff (2004). Private Charter Managers Team Up. Education Week, 23(21), 1, 15 (February 4, 2004).

Brown, H., J.R. Henig, N. Lacireno-Paquet, T.T. Holyoke, and M. Moser (2003). Scale of Operations and Locus of Control in Market- vs. Mission-Oriented Charter Schools.

Buckley, J. and S. Kuscova (2003). The Effects of Institutional Variation on Policy Outcomes: The Case of Charter Schools in the States. NY, Teacher's College, Columbia University, National Center for the Study of Privatization in Education: Occasional Paper \#79.

Chubb, J. E. and T. M. Moe (1990). Politics, Markets, and America's Schools. Washington, DC, Brookings Institution Press.

Cobb, C. D. and G. V. Glass (1999). Ethnic Segregation in Arizona Charter Schools. Education Policy Analysis Archives, 7(1). Retrieved June 15, 2004, from http://epaa.asu.edu/epaa/v7n1/.

Fiske, E. B. and H. F. Ladd (2000). When Schools Compete: A Cautionary Tale. Washington, DC, Brookings Institution Press.

Frumkin, P. and A. Andre-Clark (2000). When Missions, Markets, and Politics Collide: Values and Strategies in the Nonprofit Human Services. Nonprofit and Voluntary Sector Quarterly, 29(1, Supplement), 141-163.

Gill, B. P., P. M. Timpane, et al. (2001). Rhetoric Versus Reality: What we Know and What We Need to Know About Vouchers and Charter Schools. Santa Monica, CA, RAND.

Greene, J. P. (2000). Why School Choice Can Promote Integration. Education Week, 19(31), 72, 52.

Hassel, B. C. (1999). The Charter School Challenge. Washington, DC, Brookings Institution Press.

Henig, J. R., T. T. Holyoke, et al. (2003). Privatization, Politics, and Urban Services: The Political Behavior of Charter Schools. Journal of Urban Affairs, 25(1), 37-54.

Henig, J. R. (1994). Rethinking School Choice: Limits of the Market Metaphor. Princeton, NJ, Princeton University Press.

Kahlenberg, R. D. (2001). All Together Now: Creating Middle-Class Schools through Public School Choice. Washington, DC, Brookings Institution Press.

Lacireno-Paquet, N., T. T. Holyoke, et al. (2002). Creaming versus Cropping: Charter School Enrollment Practices in Response to Market Incentives. Educational Evaluation and Policy Analysis, 24(2), 145-158.

Miron, G. and C. Nelson (2002). What's Public about Charter Schools? Lessons Learned About Choice and Accountability. Thousand Oaks, CA, Corwin Press, Inc.

Miron, G., C. Neslon, and J. Risley. 2002. Strengthening Pennsylvania's Charter School Reform:

Findings from the Statewide Evaluation and Discussion of Relevant Policy Issues. Vol. 2003: The

Evaluation Center, Western Michigan University.

Nathan, J. (1996). Charter Schools: Creating Hope and Opportunity for American Education. San Francisco, Jossey-Bass Publishers.

National Council of Education Providers (2004). Internet Homepage. Retrieved February 2, 2004 
from http://www.educationproviders.org.

Nelson, F. H., E. Muir, et al. (2000). Venturesome Capital: State Charter School Finance Systems. Washington, DC, Office of Educational Research and Improvement, U.S. Department of Education.

No Child Left Behind Act of 2001 § 5201(3)

Peterson, P. and J. P. Greene (1998). Race Relations \& Central City Schools: It's time for an Experiment with Vouchers. Brookings Review, 16(2), 33-37.

Peterson, P. (1999). A Liberal Case for Vouchers. The New Republic, 221(14), 29-30.

Plank, D. N., D. Arsen, et al. (2000). Charter Schools and Private Profits. The School Administrator (Web Edition): 1-9.

Reform, Center for Education (2002). Answers to Frequently Asked Questions About Charter Schools.

Rothstein, R. (1998). "Charter Conundrum." The American Prospect, 9(39).

RPP International (1999). A Comparison of Charter School Legislation: Thirty Three States and the District of Columbia Incorporating Changes Through October, 1998, U.S. Department of Education.

RPP International (2000). The State of Charter Schools 2000: Fourth Year Report. Washington, DC, Office of Educational Research and Improvement, U.S./ Department of Education.

Teske, P. and M. Schneider (2001). What Research Can Tell Policymakers about School Choice. Journal of Policy Analysis and Management, 20(4), 609-631.

Vergari, S., Ed. (2002). The Charter School Landscape. Pittsburgh, PA, University of Pittsburgh Press.

Viteritti, J. P. (1999). Choosing Equality: School Choice, the Constitution, and Civil Society. Washington, DC, Brookings Institution Press.

Weisbrod, B. A. (1998). Institutional Form and Institutional Behavior. Private Action and the Public Good. W. W. Powell and E. S. Clemens. New Haven, CT, Yale University Press: 69-84.

Wells, A. S., C. Grutzik, et al. (1999). Underlying Policy Assumptions of Charter school Reform: The Multiple Meanings of a Movement. Teachers College Record 100(3): 513-535.

Wells, A. S., A. Lopez, et al. (1999). Charter Schools as Postmodern Paradox: Rethinking Social Stratification in an Age of Deregulated School Choice. Harvard Educational Review 69(2): 172-204.

Wells, A. S., Ed. (2002). Where Charter School Policy Fails: The Problems of Accountability and Equity. Sociology of Education. New York, Teachers College Press.

Witte, J. F., A. F. Shober, et al. (2003). Analyzing State Charter School Laws and Their Influence on the Formation of Charter Schools in the United States. Paper prepared for the American Political Science Association 2003 Annual Meeting, Philadelphia, PA.

\section{About the Author}

\section{Natalie Lacireno-Paquet}

The George Washington University

805 21st Street NW, Suite 601

Washington, DC 20052

Email: lacpaq@gwu.edu

Natalie Lacireno-Paquet recently received her Ph.D. in Public Policy from The 
George Washington University. Her research interests include the equity implications of education reform, specifically school choice policies, and the role of management companies in public education.

\section{Notes}

- 1. While "service to disadvantaged students" is a multifaceted concept, in this paper I examine just one facet-access. Other related and perhaps more important facets of service include examination of the quality of the schools attended by disadvantaged students, as well as their achievement in their schools of choice.

- 2. The excluded states are Connecticut, Georgia, Kansas, Ohio, and Wisconsin.

- 3. Eligibility for the Free and Reduced Price Lunch Program is used as a proxy for low-income status.

- 4. BRR-based standard errors are the recommended method of the National Center for Education Statistics for use with the SASS data because they adjust standard errors to account for nonresponse and for the complex design of the SASS. However, because the charter schools were selected with certainty the use of the weights associated with the BRR method are unnecessary. Moreover, because the assumption that the error terms are independent is violated (84 of the school districts have more than one charter school), I corrected for the correlated error terms by clustering charter schools in their host districts, using the robust cluster option in STATA.

- 5. Here EMO is defined as firm that offers comprehensive school management services in three or more schools (see Bulkley 2001). This definition will exclude those EMOs that were set up to manage one particular school, such as some EMOs in Michigan where school leaders incorporated to avoid participation in the state teacher's retirement plan.

- 6. A caveat is important here because while this article looks at what types of students are served by charter schools it is important to note that there is difficulty in distinguishing between the effects of which parents are choosing charter schools and which students are chosen by charter schools. States do not allow charter schools to discriminate, but some states allow charter schools to specify geographic boundaries for service, specify admissions criteria or to give siblings preference or to give the children of founders and staff preference over others who may want to attend, and these could allow schools to actively shape their student populations. Additionally, charters may influence their student populations through the way they advertise or describe their offerings.

- 7. While the nested nature of the data (charter schools in districts in states) appears to be a natural fit for Hierarchical Linear Modeling techniques, the peculiarities of this dataset did not permit it. First, there was not enough variation in some of the key variables at the different levels of analysis. For example, some states have fewer than 5 EMO operated schools, making the estimation of coefficients for these variables unreliable or even impossible. Second, some districts have only one charter school, and few have 5 or more, making the technical estimation at this level impossible.

- 8. Because the BRR-based standard errors are the preferred method of 
the NCES, I want to note the results of the model using the BRR-based standard errors are somewhat different, though not contradictory. Using the BRR standard errors, a number of additional variables become significant, including large-EMO (3.89), and all of the policy variables. The coefficients of variables that were significant in the cluster analysis remain significant with virtually identical magnitudes in the BRR-based standard errors model. The results of this model are available upon request from the author.

- 9. Again, for comparison purposes, I want to note the differences and similarities with results for the same model but using BRR-based standard errors. In the BRR model, the standard errors tend to be smaller and thus more variables reach statistical significance. While all of the variables in the cluster analysis remain significant, with virtually identical coefficients, variables that are newly significant include: parental service requirement (2.33), total enrollment (0.003), and funding varies by grade level (-5.58). The results of this model are available upon request from the author.

The World Wide Web address for the Education Policy Analysis Archives is epaa.asu.edu

\section{Editor: Gene V Glass, Arizona State University}

\section{Production Assistant: Chris Murrell, Arizona State University}

General questions about appropriateness of topics or particular articles may be addressed to the Editor, Gene V Glass, glass@asu.edu or reach him at College of Education, Arizona State University, Tempe, AZ 85287-2411. The Commentary Editor is Casey D. Cobb: casey.cobb@unh.edu.

\section{EPAA Editorial Board}

$\begin{array}{ll}\text { Michael W. Apple } & \text { David C. Berliner } \\ \text { University of Wisconsin } & \text { Arizona State University } \\ \text { Greg Camilli } & \text { Linda Darling-Hammond } \\ \text { Rutgers University } & \text { Stanford University } \\ \text { Sherman Dorn } & \text { Mark E. Fetler } \\ \text { University of South Florida } & \text { California Commission on Teacher } \\ \text { Gustavo E. Fischman } & \text { Credentialing } \\ \text { Arizona State Univeristy } & \text { Richard Garlikov } \\ \text { Thomas F. Green } & \text { Birmingham, Alabama } \\ \text { Syracuse University } & \text { Aimee Howley } \\ \text { Craig B. Howley } & \text { Ohio University } \\ \text { Appalachia Educational Laboratory } & \text { William Hunter } \\ & \text { University of Ontario Institute of } \\ & \text { Technology }\end{array}$


Patricia Fey Jarvis

Seattle, Washington

Benjamin Levin

University of Manitoba

Les McLean

University of Toronto

Michele Moses

Arizona State University

Anthony G. Rud Jr.

Purdue University

Michael Scriven

University of Auckland

Robert E. Stake

University of Illinois-UC

Terrence G. Wiley

Arizona State University
Daniel Kallós

Umeå University

Thomas Mauhs-Pugh

Green Mountain College

Heinrich Mintrop

University of California, Los Angeles

Gary Orfield

Harvard University

Jay Paredes Scribner

University of Missouri

Lorrie A. Shepard

University of Colorado, Boulder

Kevin Welner

University of Colorado, Boulder

John Willinsky

University of British Columbia

\title{
EPAA Spanish \& Portuguese Language Editorial Board
}

\author{
Associate Editors \\ Gustavo E. Fischman \\ Arizona State University \\ \& \\ Pablo Gentili \\ Laboratório de Políticas Públicas \\ Universidade do Estado do Rio de Janeiro
}

\author{
Founding Associate Editor for Spanish Language (1998-2003) \\ Roberto Rodríguez Gómez \\ Universidad Nacional Autónoma de México
}

\section{Argentina}

- Alejandra Birgin

Ministerio de Educación, Argentina

Email: abirgin@me.gov.ar

- Mónica Pini

Universidad Nacional de San Martin, Argentina

Email: mopinos@hotmail.com,

- Mariano Narodowski

Universidad Torcuato Di Tella, Argentina

Email:

- Daniel Suarez

Laboratorio de Politicas Publicas-Universidad de Buenos Aires, Argentina

Email: daniel@lpp-buenosaires.net 
- Marcela Mollis (1998-2003)

Universidad de Buenos Aires

\section{Brasil}

- Gaudêncio Frigotto Professor da Faculdade de Educação e do Programa de Pós-Graduação em Educação da Universidade Federal Fluminense, Brasil

Email: grigotto@globo.com

- Vanilda Paiva

Email:vppaiva@terra.com.br

- Lilian do Valle

Universidade Estadual do Rio de Janeiro, Brasil

Email: Ivalle@infolink.com.br

- Romualdo Portella do Oliveira Universidade de São Paulo, Brasil

Email: romualdo@usp.br

- Roberto Leher Universidade Estadual do Rio de Janeiro, Brasil

Email: rleher@uol.com.br

- Dalila Andrade de Oliveira Universidade Federal de Minas Gerais, Belo Horizonte, Brasil

Email: dalila@fae.ufmg.br

- Nilma Limo Gomes

Universidade Federal de Minas Gerais, Belo Horizonte

Email: nilmagomes@uol.com.br

- Iolanda de Oliveira

Faculdade de Educação da Universidade Federal Fluminense, Brasil

Email: iolanda.eustaquio@globo.com

- Walter Kohan Universidade Estadual do Rio de Janeiro, Brasil

Email: walterko@uol.com.br

- María Beatriz Luce (1998-2003)

Universidad Federal de Rio Grande do Sul-UFRGS

- Simon Schwartzman (1998-2003)

American Institutes for Resesarch-Brazil

\section{Canadá}

- Daniel Schugurensky

Ontario Institute for Studies in Education, University of Toronto, Canada

Email: dschugurensky@oise.utoronto.ca

\section{Chile}

- Claudio Almonacid Avila Universidad Metropolitana de Ciencias de la Educación, Chile

Email: caa@rdc.cl

- María Loreto Egaña

Programa Interdisciplinario de Investigación en Educación (PIIE), Chile

Email: legana@academia.cl 


\section{España}

- José Gimeno Sacristán

Catedratico en el Departamento de Didáctica y Organización Escolar de la Universidad de Valencia, España

Email: Jose.Gimeno@uv.es

- Mariano Fernández Enguita

Catedrático de Sociología en la Universidad de Salamanca. España

Email: enguita@usal.es

- Miguel Pereira

Catedratico Universidad de Granada, España

Email: mpereyra@aulae.es

- Jurjo Torres Santomé

Universidad de A Coruña

Email: jurjo@udc.es

- Angel Ignacio Pérez Gómez

Universidad de Málaga

Email: aiperez@uma.es

- J. Félix Angulo Rasco (1998-2003)

Universidad de Cádiz

- José Contreras Domingo (1998-2003)

Universitat de Barcelona

\section{México}

- Hugo Aboites

Universidad Autónoma Metropolitana-Xochimilco, México

Email: aavh4435@cueyatl.uam.mx

- Susan Street

Centro de Investigaciones y Estudios Superiores en Antropologia Social

Occidente, Guadalajara, México

Email: slsn@mail.udg.mx

- Adrián Acosta

Universidad de Guadalajara

Email: adrianacosta@compuserve.com

- Teresa Bracho

Centro de Investigación y Docencia Económica-CIDE

Email: bracho dis1.cide.mx

- Alejandro Canales

Universidad Nacional Autónoma de México

Email: canalesa@servidor.unam.mx

- Rollin Kent

Universidad Autónoma de Puebla. Puebla, México

Email: rkent@puebla.megared.net.mx

- Javier Mendoza Rojas (1998-2003)

Universidad Nacional Autónoma de México

- Humberto Muñoz García (1998-2003)

Universidad Nacional Autónoma de México

\section{Perú}

- Sigfredo Chiroque 
Instituto de Pedagogía Popular, Perú

Email: pedagogia@chavin.rcp.net.pe

- Grover Pango

Coordinador General del Foro Latinoamericano de Políticas Educativas,

Perú

Email: grover-eduforo@terra.com.pe

\section{Portugal}

- Antonio Teodoro

Director da Licenciatura de Ciências da Educação e do Mestrado Universidade Lusófona de Humanidades e Tecnologias, Lisboa, Portugal

Email: a.teodoro@netvisao.pt

\section{USA}

- Pia Lindquist Wong

California State University, Sacramento, California

Email: wongp@csus.edu

- Nelly P. Stromquist

University of Southern California, Los Angeles, California

Email: nellystromquist@juno.com

- Diana Rhoten

Social Science Research Council, New York, New York

Email: rhoten@ssrc.org

- Daniel C. Levy

University at Albany, SUNY, Albany, New York

Email: Dlevy@uamail.albany.edu

- Ursula Casanova

Arizona State University, Tempe, Arizona

Email: casanova@asu.edu

- Erwin Epstein

Loyola University, Chicago, Illinois

Email: eepstei@wpo.it.luc.edu

- Carlos A. Torres

University of California, Los Angeles

Email: torres@gseisucla.edu

- Josué González (1998-2003)

Arizona State University, Tempe, Arizona 